\title{
ANALISIS DINAMIKA PERMASALAHAN IMPLEMENTASI ANGGARAN PEMERINTAH DAERAH DI INDONESIA
}

\author{
Rahmat Salam \\ Universitas Muhammadiyah Jakarta \\ Email: rahmat.salam@umj.ac.id
}

\begin{abstract}
Abstrak
Proses penganggaran merupakan pusat dari setiap administrasi baik itu Pemerintah pusat, pemerintah daerah dan swasta karena kendali keuangan mungkin merupakan alat koordinasi yang paling efektif. Cakupan dan sifat operasi pemerintah secara keseluruhan ditentukan oleh alokasi alokasi untuk berbagai program. Sebenarnya sifat manusia tidak pernah terbukti dibandingkan ketika manusia berjuang untuk mendapatkan bagian dana yang lebih besar dari yang biasa. Makalah ini mengkaji penganggaran di tingkat pemerintah daerah, persiapannya, masalah dan prospeknya. Studi tersebut menemukan bahwa terdapat kesenjangan yang lebar antara rencana anggaran dan pelaksanaannya yang mengakibatkan tidak terpenuhinya janjijanji politik dan tidak terpenuhinya harapan masyarakat yang semakin tinggi. Ketidakpuasan yang meluas dari massa terhadap pemerintah daerah berkontribusi besar pada rendahnya laju pembangunan masyarakat lokal. Makalah ini membuat beberapa rekomendasi yang akan mengurangi timbulnya defisit anggaran di Pemerintah.
\end{abstract}

Kata Kunci: Penganggaran, Implementasi Anggaran, Pemerintah Daerah.

\begin{abstract}
The budgeting process is central to every administration be it the central government, local governments and the private sector because financial control is perhaps the most effective coordination tool. The scope and nature of government operations as a whole are determined by the allocations for the various programs. In fact, human nature has never been proven compared to when humans struggle to get a larger than usual share of the funds. This paper examines budgeting at the local government level, its preparation, problems and prospects. The study found that there was a wide gap between the budget plan and its implementation which resulted in the failure to fulfill political promises and the increasingly high expectations of society. The widespread dissatisfaction of the masses with the local government contributed greatly to the slow pace of local community development. This paper makes several recommendations that will reduce the incidence of budget deficits in the Government.
\end{abstract}

Keywords: Budgeting, Budget Implementation, Local Government.

\section{A. PENDAHULUAN}

Politik penganggaran pemerintah daerah berpusat pada keinginan atau preferensi manusia yang menggarisbawahi persiapan, persetujuan dan pelaksanaan anggaran. Seperti yang diamati Perez \& Robson (1999), penganggaran berkaitan dengan tujuan manusia. Dengan kata lain, bagaimana mereka bisa tergerak untuk bekerja sama? Bagaimana mereka dapat menemukan cara untuk menangani masalah berat secara efektif? Melayani berbagai 
tujuan, anggaran bisa menjadi banyak hal; tindakan politik, rencana kerja, ramalan, sumber pencerahan, alat kebingungan, mekanisme kontrol, pelarian dari pembatasan, alat tindakan, penghambat kemajuan, bahkan doa agar kekuatan itu menjadi akan menangani dengan lembut aspirasi terbaik dari orang-orang yang salah.

Proses penganggaran di pemerintah daerah menekankan pada aspek manusia dan perilaku perkiraan. Ini secara khusus berkaitan dengan menjawab pertanyaan "siapa mendapatkan apa, bagaimana, kapan dan mengapa dari sumber keuangan pemerintah daerah. Oleh karena itu, yang menjadi tugas pokok makalah ini adalah mengkaji secara kritis penganggaran di tingkat pemerintah daerah dengan maksud menjelaskan persiapan, permasalahan yang ada dan menyoroti prospeknya. Dalam pandangan Tuasikal (2013), anggaran merupakan laporan tahunan yang komprehensif dari keadaan perekonomian bangsa. Ia meninjau masalah ekonomi dan sosial yang lama dan mengantisipasi yang baru. Ini mensurvei prospek masa depan ekonomi dan menerjemahkan masalah menjadi barang atau tujuan. Instrumen kebijakan moneter dan fiskal, intervensi ekonomi langsung yang mengukur perubahan kelembagaan kemudian dipilih dan dipangkas agar sesuai dengan tujuan yang diinginkan sehingga keseimbangan internal dan eksternal suatu negara dapat dipulihkan.

Miller \& O'Leary (1997), melihat anggaran sebagai rencana yang dinyatakan dalam istilah kuantitatif dan biasanya moneter, yang mencakup periode waktu tertentu. Biasanya, jangka waktu yang dicakup adalah satu tahun dan ini menjadikannya rencana jangka pendek. Praktisnya, semua organisasi besar, baik di sektor swasta maupun publik menyiapkan anggaran tahunan. Bagi banyak orang, istilah ini berkonotasi dengan pengaruh yang menahan tindakan, oleh karena itu banyak orang baik sebagai individu atau anggota organisasi tampaknya mengembangkan sikap negatif terhadap penganggaran. Karena sumber daya yang tersedia tidak selalu cukup untuk melayani kebutuhan atau peluang yang akan dilayani oleh organisasi, penganggaran tetap menjadi instrumen paling taktis untuk pengambilan keputusan serta alokasi sumber daya.

Anggaran pemerintah daerah adalah rencana keuangan yang komprehensif dari pendapatan dan pengeluarannya dalam jangka waktu tertentu yang menjadi dasar operasional pemerintah selama periode tersebut. Ini adalah rencana alokasi keuangan yang diusulkan yang dirancang secara sistematis untuk berbagai layanan dan program dengan proyeksi pendapatan yang terperinci dan dihitung dengan cermat dari semua sumber pendapatannya. Anggaran pemerintah daerah pada umumnya untuk jangka waktu dua belas bulan, sehingga sering disebut dengan Estimasi Tahunan. Anggaran tahunan adalah rencana keuangan sekaligus dokumen politik. Faktanya, anggaran dikatakan lebih merupakan dokumen politik 
karena baik tujuan anggaran maupun alokasinya berkaitan erat dengan politik dan diatur oleh pertimbangan politik (Abdullah \& Halim, 2006).

Anggaran memberikan strategi yang efektif untuk pengelolaan keuangan yang efisien. Sebagai rencana sistematis proyeksi pendapatan dan pengeluaran, dengan pemeriksaan bawaan, anggaran berfungsi sebagai instrumen kontrol yang kuat. Oleh karena itu Due dan Friedlander (1967) memahami anggaran sebagai "rencana keuangan yang berfungsi sebagai dasar untuk pengambilan keputusan pengeluaran dan pengendalian pengeluaran selanjutnya. Langkah-langkah yang dilembagakan dan menurut undang-undang disediakan untuk memastikan bahwa alokasi keuangan dibelanjakan untuk tujuan mereka dipilih dan sesuai dengan hukum dan peraturan. Karena itu, ia memeriksa pemborosan dana publik. Ini juga memastikan bahwa dana publik yang tersedia tersebar di berbagai layanan dan program penting, mempromosikan ekonomi dalam operasi pemerintah dan sebagai konsekuensinya memastikan administrasi yang efisien dan efektif.

Anggaran merupakan kewenangan bagi pejabat publik untuk memungut pajak, retribusi, dan denda. Ini juga merupakan otorisasi bagi pejabat untuk membelanjakan pendapatan publik sebagaimana ditentukan dalam alokasi yang disetujui dan sesuai dengan nota keuangan. Otorisasi oleh badan legislatif mempromosikan prinsip kedaulatan rakyat yang dijalankan melalui prinsip mandate (Sabrina, 2009). Ini juga berfungsi sebagai perangkat penting untuk menghubungkan total pengeluaran dengan total pendapatan yang menciptakan tantangan untuk memenuhi kebutuhan perkiraan pendapatan. Anggaran adalah sarana ilmiah untuk kualifikasi dan pengukuran layanan dalam hal pengeluaran dalam periode tertentu. Menurut Ogunna (1996) anggaran pemerintah dapat dilihat sebagai instrumen untuk penciptaan lapangan kerja. Melalui penganggaran, peluang kerja diciptakan dengan menyediakan proyek pengembangan modal. Oleh karena itu, ini merupakan sarana untuk mengurangi tingkat pengangguran yang tinggi dalam masyarakat kita dan dengan demikian memeriksa penyimpangan pedesaan-perkotaan.

Dari uraian diatas peneliti tertarik untuk melakukan penelitian tentang anggaran pemerintah daerah. Kesenjangan antara rencana anggaran dengan pelaksanaannya sehingga tidak terpenuhi harapan masyarakat yang menyebabkan meluasnya rasa ketidakpuasan masyarakat kepada pemerintah daerah. Disamping itu pada makalah ini akan di buar beberapa rekomendasi untuk mengurangi deficit anggaran pemerintah tersebut. 


\section{B. METODE}

Penelitian dilakukan dengan menggunakan metode kualitatif. Dengan metode kualitatif ini, peneliti berusaha mengungkap esensi universal dari fenomena yang dialami secara pribadi oleh sekelompok individu secara mendalam (Estenberg, 2002). Pengumpulan data dilakukan dengan beberapa teknik, antara lain teknik observasi, dan studi dokumentasi. Analisis data dilakukan melalui tiga proses analisis yaitu pengkodean, penggabungan kodekode yang muncul menjadi tema, verifikasi tema melalui teori dan wawancara tindak lanjut, serta penarikan kesimpulan (Creswell, 2010).

\section{HASIL DAN PEMBAHASAN}

Anggaran pemerintah daerah harus memuat enam elemen berikut. Yang pertama adalah tujuannya. Tujuan mengatur seluruh isi anggaran dan membimbing perilaku pejabat selama pelaksanaannya. Kedua, tinjauan singkat kinerja anggaran tahun sebelumnya. Ini harus mencakup ringkasan pendapatan dan pengeluaran aktual sehubungan dengan perkiraan mereka. Ketiga adalah perkiraan rinci pendapatan (berulang dan modal). Perkiraan pendapatan harus memberikan rincian penerimaan yang diharapkan dari semua sumber dan diatur di kepala daerah. Rekomendasi kepala daerah tentang ukuran pendapatan yang diperlukan untuk membiayai pengeluaran yang diproyeksikan harus diwujudkan. Keempat adalah perkiraan pengeluaran secara rinci. Alokasi keuangan yang diusulkan untuk layanan dan program dikategorikan di bawah Kepala dan sub-Kepala. Perkiraan Belanja Modal dibuat berdasarkan sektor (departemen). Perbandingan antara pengeluaran tahun-tahun lalu dan sekarang harus dibuat. Kelima, anggaran juga harus berisi informasi rinci tentang tingkat pengeluaran yang diusulkan dengan penjelasan yang tepat yang berupaya untuk menjustifikasi penyimpangan dari tingkat pengeluaran sebelumnya pada anggaran tahunan sebelumnya. Keenam, anggaran yang direncanakan dengan baik harus berisi Lampiran yang berisi jadwal tambahan yang dirancang untuk memfasilitasi pemahaman yang cepat dan tepat tentang hubungan antar berbagai komponen perkiraan (Kluvers, 2001).

Anggaran yang baik harus memiliki empat kualitas utama, yaitu kelengkapan penyediaannya; fleksibilitas dalam arti bahwa tingkat keleluasaan administratif yang wajar harus diberikan; reliabilitas yang mengandung arti bahwa seluruh data yang menjadi dasar penyusunan dan penetapan anggaran harus mencukupi secara kuantitas, akurat dan relevan secara kualitas; Integritas yang berarti bahwa seluruh ketentuan anggaran harus dirumuskan dan ditetapkan sedemikian rupa sehingga program fiskal harus dilaksanakan secara 
substansial dengan cara dan cara dan untuk tujuan disediakan (Franklin \& Raadshcelders, 2003).

Tujuan utama dari perkiraan pemerintah daerah adalah:

1. Untuk memberikan rencana tindakan keuangan. Anggaran menjabarkan dalam istilah keuangan tujuan yang ingin dicapai oleh pemerintah daerah. Itu diperlukan sebagai rencana tindakan; oleh karena itu, semua kegiatan harus diarahkan pada realisasi tujuan. Perlu dicatat pada titik ini bahwa tidak ada variasi yang diizinkan segera setelah anggaran disiapkan dan disetujui.

2. Untuk memberikan kewenangan hukum untuk mengeluarkan pengeluaran. Karena kegiatan keuangan pemerintah daerah tunduk pada ketentuan pedoman atau peraturan pemerintah daerah, maka pedoman tersebut memberikan dukungan hukum untuk melakukan pengeluaran. Setiap pengeluaran yang tidak disediakan dalam anggaran yang disetujui menjadi ilegal.

3. Untuk menyediakan mekanisme untuk memastikan bahwa kontrol yang memadai dipertahankan atas pengeluaran dan pendapatan. Nota keuangan menyediakan klasifikasi pendapatan dan pengeluaran yang seragam untuk diadopsi oleh semua dewan pemerintah daerah di seluruh negeri. Ini memastikan bahwa anggaran tidak dapat dimanipulasi dengan cara apa pun. Pengeluaran yang terjadi dari waktu ke waktu harus dicatat untuk menghindari pengeluaran berlebih

4. Mampu menetapkan posisi keuangan dewan pemerintah daerah. Perlu dicatat bahwa angka pengeluaran dan pendapatan yang digabungkan menjadi dasar laporan keuangan tahunan harus mengungkapkan posisi keuangan pemerintah daerah pada awal dan akhir tahun tertentu. Posisi dewan pemerintah lokal ini harus dijaga atau diketahui dari waktu ke waktu.

Beberapa pendekatan yang ada dalam penganggaran yaitu: Penganggaran ujung terbuka; Penganggaran alternatif; Anggaran pagu tetap; Pengukuran kerja dan biaya unit; Penganggaran daftar prioritas; Anggaran dasar nol. Metode-metode ini saling eksklusif, tetapi beberapa digunakan dalam estimasi anggaran dan lainnya dalam pengendalian anggaran.

Penganggaran ujung terbuka adalah pendekatan yang memungkinkan pejabat merekomendasikan satu perkiraan untuk tahun yang bersangkutan. Misalnya kepala daerah dapat memilih jenis persetujuan ini. Dalam hal ini, dia membuat daftar semua proyek sebanyak mungkin, karena tidak ada batasan yang diberlakukan pada listingnya. 
Sistem penganggaran alternatif adalah metode dimana tambahan estimasi anggaran disiapkan sebagai alternatif dari anggaran utama. Misalnya, jika perkiraan anggaran dibuat per item, jumlah alternatif ditetapkan berdampingan dan jumlah itu bertindak sebagai panduan pengeluaran alternatif. Penganggaran alternatif membantu dalam membuat anggaran yang kurang otoritatif dan final.

Anggaran pagu tetap, berdasarkan rencana ini, pagu tetap ditetapkan sebelumnya yang tidak dapat melebihi perkiraan anggaran bawahan. Dalam hal ini kepala daerah dapat memberikan instruksi khusus kepada setiap departemen mengenai angka pagu total yang tidak boleh dilampaui oleh suatu departemen dalam membuat estimasi anggaran. Masalah yang dihadapi dalam metode plafon tetap adalah masalah pengaturan program yang terlalu tinggi atau terlalu rendah. Namun, anggaran pagu tetap menjadi pedoman bagi bawahan dalam menyusun perkiraan anggarannya.

Pengukuran beban kerja dan biaya unit adalah metode untuk menentukan unit pekerjaan atau proyek dengan biaya satuannya. Dengan metode ini, dimungkinkan untuk menentukan berapa biaya untuk melakukan setiap unit kerja. Masalah yang dialami dalam pendekatan ini adalah kurangnya informasi. Karena pengukuran beban kerja dan unit costing dapat membantu pengambil keputusan untuk menghitung jumlah proyek yang sedang dikerjakan, hal itu tidak dapat menunjukkan berapa banyak proyek yang harus diselesaikan maupun ekonomi, sosial dan politiknya yang tidak jelas.

Peningkatan-penurunan penganggaran adalah pendekatan di mana perkiraan anggaran mengidentifikasi item demi item meningkat atau menurun dibandingkan dengan anggaran tahun sebelumnya. Penjelasan khusus diperlukan untuk kenaikan tersebut. Kesalahan mendasar dengan pendekatan ini adalah kenyataan bahwa ia tidak memerlukan perbandingan nilai-nilai relatif lama dan baru.

Daftar Prioritas, pendekatan ini mengharuskan penaksir anggaran untuk menunjukkan prioritas item yang termasuk dalam permintaan anggaran. Pendekatan ini membantu pembuat keputusan untuk menentukan kemungkinan area di mana pemotongan atau pengikisan barang dapat dilakukan.

Penganggaran berbasis nol, pendekatan ini mencakup penetapan tujuan program, evaluasi, dan peninjauan semua program secara sistematis dalam hal keluaran dan biaya; untuk menekankan pengambilan keputusan manajemen (Froot \& Stein, 1998).

Pendekatan pragmatis terhadap penganggaran berbasis nol menawarkan kepada pemerintah daerah alat yang fleksibel untuk digunakan dalam memikirkan kembali dan mengurangi program untuk memastikan keluaran kinerja dan pengurangan biaya. Mereka 
juga dapat menggunakan pendekatan ini untuk mengurangi atau menghilangkan program prioritas rendah; meningkatkan efektivitas program dengan tinjauan dan penyesuaian terusmenerus dan mengalihkan lebih banyak dana ke program berdampak tinggi.

Namun, pendekatan ini terlalu menuntut kapasitas manajemen di banyak pemerintah daerah. Ini membutuhkan administrasi yang efektif, komunikasi yang baik, dan pelatihan khusus. Otoritas lokal yang akan menggunakan pendekatan ini harus terampil dalam mengidentifikasi unit keputusan pendekatan, pendekatan ini harus terampil dalam mengidentifikasi unit keputusan yang tepat mengembangkan data yang memadai untuk menghasilkan analisis yang efektif menentukan tingkat minimum upaya, dan peringkat program serupa dan berbeda juga. seperti menangani data dalam jumlah besar.

Pemerintah daerah merasa lebih nyaman untuk menyiapkan anggarannya pada penganggaran item-baris. Di bawah pendekatan ini, kegiatan homogen dikelompokkan menjadi program yang masing-masing memiliki tujuan sebagai berikut:

1. Menjadi pusat biaya untuk mengumpulkan rincian selama penyusunan anggaran tahunan.

2. Untuk pusat kendali selama pelaksanaan anggaran tahunan yang disetujui untuk tujuan akuntansi keuangan.

3. Menjadi titik acuan dalam revisi anggaran tahunan tersebut dan untuk keperluan audit transaksi keuangan.

Penyusunan anggaran pemerintah daerah harus sesuai dengan nota keuangan yang mengatur klasifikasi pendapatan dan belanja yang seragam untuk diadopsi oleh semua pemerintah daerah di semua daerah. Klasifikasi perkiraan yang seragam juga akan berlaku untuk akun semua pemerintah daerah. Hal ini akan memungkinkan perbandingan dibuat setiap saat, sepanjang tahun antara ketentuan di bawah kepala dan sub-kepala dalam perkiraan dan kepala dan sub-kepala yang sama dalam catatan akuntansi. Anggaran atau Perkiraan biasanya disiapkan dalam empat bagian yaitu:

1. Pendapatan Berulang

2. Pengeluaran Berulang termasuk gaji dan tunjangan pegawai.

3. Penerimaan Modal

4. Belanja modal.

\section{Masalah yang Berhubungan dengan Anggaran di Pemerintah Daerah}

Masalah yang berhubungan dengan anggaran di Pemerintah Daerah di Indonesua antara lain sebagai berikut: 
1. Keuangan

Kurangnya sumber daya keuangan secara umum, aliran dana yang tidak dapat diprediksi, terutama untuk pemerintah daerah yang sangat tidak dapat berjalan, menimbulkan masalah serius dalam penganggaran di pemerintah daerah. Perencanaan anggaran pemerintah daerah didasarkan pada kemungkinan pendapatan yang diharapkan sedangkan pelaksanaannya bergantung pada ketersediaan rencana yang diproyeksikan dengan fondasi keuangan yang sangat lemah sedangkan, di sisi lain, pendapatan yang diproyeksikan tidak pernah terwujud.

2. Kapasitas eksekutif yang rendah

Kapasitas eksekutif yang rendah merupakan faktor serius yang bertentangan dengan perumusan anggaran yang efektif dan implementasi di pemerintah daerah seperti yang dicatat dengan tepat oleh Kluver (2001), pemerintah daerah memiliki kualitas staf yang rendah di bidang operasi utama mereka. Pejabat kunci ini termasuk bendahara daerah, pejabat perencanaan dan penganggaran, kepala pejabat akun, kepala departemen profesional (Pertanian, Kesehatan, pekerjaan, penganggaran). Berhasil atau tidaknya perencanaan dan pelaksanaan anggaran bergantung pada kompetensi profesional dan teknis dari para pejabat kunci tersebut. Sayangnya, ada harapan besar akan petugas yang berkualitas dan berpengalaman di bidang-bidang utama ini.

3. Non-partisipasi oleh staf manajemen

Penyusunan anggaran seringkali dianggap hanya sebagai tanggung jawab bendahara dan stafnya. Pejabat senior lainnya termasuk kepala daerah dan kepala SKPD hampir tidak berpartisipasi secara aktif dalam penyusunan perkiraan tahunan. Hal ini membuat keseluruhan latihan kekurangan masukan pengambilan keputusan yang serius dari staf manajemen. Akibatnya, proses anggaran sering kali menjadi rutin dan hasilnya sering kali memperbarui perkiraan tahun sebelumnya.

4. Tidak adanya petugas perencanaan dan anggaran

Perencanaan anggaran adalah bisnis petugas perencanaan dan anggaran. Namun, terlihat bahwa sebagian besar pemerintah daerah tidak memiliki pejabat perencanaan dan anggaran. Sabrina (2009) mencatat bahwa pemerintah daerah tidak memiliki organisasi perencanaan dan penganggaran atau unit anggaran khusus yang bertanggung jawab untuk penelitian dan perencanaan anggaran. Hasil akhirnya adalah ketidakefektifan dalam perencanaan dan pelaksanaan anggaran. 
5. Ketidakpatuhan terhadap ketentuan memorandum keuangan

Model memorandum keuangan adalah panduan untuk pekerjaan menyeluruh tentang penganggaran. Tetapi ternyata, karena panduannya terperinci, banyak petugas tidak mematuhinya, lebih memilih untuk melewati sebagian besar langkah.

6. Kurangnya Keterlibatan Masyarakat

Pemerintah daerah tidak memiliki perangkat yang layak untuk keterlibatan kepemimpinan masyarakat dalam perumusan anggaran di mana para pemimpin ini dapat membantu dalam mengidentifikasi dan mengatur prioritas masyarakat, mengembangkan strategi untuk implementasi penuh sumber daya lokal dan mobilisasi masyarakat untuk berpartisipasi dalam penggalangan dana dan pelaksanaan proyek.

7. Penundaan yang berlebihan oleh pemerintah pusat.

Pemerintah pusat bagian biasanya menunda pengiriman surat panggilan yang menjadi dasar untuk persiapan perkiraan proyek. Jika surat edaran tidak datang lebih awal, pemerintah daerah akan terkendala karena waktu yang mereka miliki sangat sedikit untuk menyiapkan perkiraannya. Pada saat waktu terlalu singkat, para pejabat hanya akan membersihkan perkiraan tahun sebelumnya dan mengirimkannya. Ini bertentangan dengan semangat penganggaran. Selain hal-hal di atas, penundaan juga dialami saat perkiraan dikirim ke pemerintah pusat. Hal ini menyebabkan banyak pemerintah daerah beroperasi tanpa anggaran. Tentu saja, situasi seperti ini tidak hanya mendorong terjadinya fraud tetapi juga menimbulkan kecurangan akuntansi (Mutiarin, 2012).

8. Strategi penganggaran item baris

Konstanta serius lainnya dalam penganggaran pemerintah daerah adalah penganggaran item baris di mana perkiraan, yang sangat rinci dibuat secara samarsamar tanpa menentukan dalam banyak kasus keluaran pasti yang ingin dicapai, seperti jumlah kilometer jalan yang akan dibangun atau dirawat dengan jumlah tersebut jumlah uang yang dipilih, jumlah hektar lahan yang akan diolah dan jumlah blok kelas yang akan dibangun.

9. Pendekatan penganggaran incremental

Terkait erat dengan penganggaran item merupakan pendekatan penganggaran inkremental yang digunakan oleh pemerintah daerah untuk diadopsi. Ini merupakan kendala serius dalam penganggaran di pemerintah daerah karena merupakan perumusan anggaran pada alokasi suara yang tidak rasional. Dalam penyusunan anggaran tambahan, pejabat sebagai masalah kebijakan dan praktik, hanya membuat 
persentase kenaikan tertentu dari angka tahun sebelumnya tanpa kriteria obyektif yang dapat diukur. Tidak ada dasar rasional untuk sampai pada perkiraan pendapatan dan pengeluaran. Lebih sering daripada tidak, ketika komite keuangan dan tujuan umum mempertimbangkan proposal anggaran, ia tidak menerapkan kriteria obyektif untuk meningkatkan atau memangkas proposal pengeluaran untuk berbagai departemen kecuali dipandu oleh angka anggaran tahun-tahun sebelumnya dan partikularistik tertentu, seksi, politik dan pertimbangan subjektif lainnya. Efek negatif serius dari anggaran tambahan adalah sindrom belanja besar-besaran di akhir tahun fiskal. Dengan praktik ini, para pengawas suara dalam dua bulan terakhir tahun keuangan dengan panik dan tergesa-gesa menghabiskan sisa suara mereka dengan cara apa pun, rasional dan irasional untuk mencegah suara atau alokasi dari "jatuh" seolah-olah kehidupan pemerintahan berakhir pada akhir tahun fiskal.

Menurut Thompson (1987) anggaran tambahan "cenderung mengarah pada kebijakan pengeluaran pemerintah yang statis. Faktanya, praktik item baris dan penganggaran inkremental cenderung melanggengkan status quo, mendorong ketidakaktifan, dan dapat menyebabkan stagnasi. Terakhir, kurangnya data dan pencatatan yang tepat akibat buruknya pencacahan daerah dan sumber penghasil pendapatan. Pengambilan keputusan yang rasional bergantung pada data yang memadai dan andal. Terlihat bahwa pemerintah daerah lemah dalam pencatatan, pengumpulan data dan dokumentasi yang tepat yang merupakan prasyarat penting untuk perumusan dan pelaksanaan anggaran yang efisien.

\section{Prospek Penganggaran di Pemerintah Daerah.}

Prospek penganggaran di pemerintah daerah bisa sangat cerah jika rekomendasi berikut ini dapat diikuti;

1. Semua proyek yang direncanakan untuk dimasukkan dalam anggaran harus berada dalam sumber daya pemerintah daerah. Proyek tidak boleh dimulai jika sumber dana tidak pasti.

2. Perkiraan tahunan (anggaran) adalah tanggung jawab semua pejabat kunci di pemerintah daerah. Oleh karena itu, ini bukan tanggung jawab Bendahara saja. Sebagai pelaksanaan perusahaan, hal itu harus ditanggapi dengan serius oleh mereka yang berkepentingan. Oleh karena itu, waktu eksekutif harus dialokasikan untuk latihan.

3. Pelaku anggaran harus menyadari bahwa pengeluaran dana publik memerlukan biaya peluang. Dalam arti tertentu, membuat pilihan yang bijaksana untuk memastikan 
bahwa preferensi masyarakat yang penting tersedia, sementara kebutuhan yang tidak terlalu mendesak ditunda, untuk tindakan di masa depan. Dengan kata lain, pejabat harus peka terhadap lingkungan khusus Pemerintah daerah mereka, dan anggaran harus memadai untuk menanggapi kekhasan tersebut.

4. Pemerintah pusat harus menyediakan dana bagi Pemerintah Lokal secara memadai dan tepat waktu. Jika dana tidak tersedia, penganggaran akan menjadi latihan teoritis belaka.

5. Pemerintah pusat di sisi lain harus merilis panggilan melingkar dalam waktu dan juga, menyetujui anggaran dengan cepat. Dengan demikian, pemerintah pusat akan berada dalam posisi untuk memantau operasi di pemerintah daerah.

6. Ketika perkiraan tahunan disetujui, Pemerintah pusat harus memastikan bahwa Pemerintah Daerah mematuhinya untuk mencegah ketidakdisiplinan anggaran. Auditor Internal harus merupakan pejabat dengan senioritas yang memadai sehingga mereka dapat membantu dalam menerapkan disiplin anggaran di pemerintah daerah.

7. Akhirnya, pemerintah daerah harus membentuk unit perencanaan dan penganggaran yang dipimpin oleh pejabat anggaran dan perencanaan yang berkualifikasi baik dan berpengalaman yang harus diberi tanggung jawab untuk penelitian dan perumusan anggaran, studi proyek dan penilaian kinerja anggaran.

\section{KESIMPULAN}

Keberhasilan atau kegagalan organisasi mana pun sangat bergantung pada sistem penganggarannya. Sumber daya keuangan yang memadai, pengelolaan dan keekonomian yang hati-hati dalam pemanfaatan dana yang tersedia; tersedianya sejumlah personel yang berkualifikasi baik, kompeten secara teknis dan profesional, berdedikasi tinggi dan bermotivasi tinggi, ketua dan anggota dewan yang tercerahkan, berpengalaman dan berdedikasi tinggi, serta dukungan dan keterlibatan masyarakat merupakan faktor yang sangat diperlukan untuk perumusan dan pelaksanaan anggaran yang efisien di pemerintah daerah. tingkat. Ketika dewan pemerintah daerah memulai persiapan anggarannya, mereka disarankan untuk berhati-hati dalam penyusunan dan perumusan anggaran, serta secara taat mematuhi ketentuan anggaran yang telah disetujui. Masalah yang teridentifikasi (kendala anggaran) dan rekomendasi yang dibuat dalam makalah ini harus benar-benar diperhatikan agar Pemerintah Daerah mencapai efektivitas dan efisiensi yang diinginkan dalam perumusan dan pelaksanaan anggaran. 


\section{DAFTAR PUSTAKA}

Due, J. F., \& Fredlaender, A. F. (1967) Government Finance Homewood Richard Dilrwin Inc.

Perez, L. F. R., \& Robson, K. (1999). Ritual legitimation, de-coupling and the budgetary process: managing organizational hypocrisies in a multinational company. Management Accounting Research, 10(4), 383-407.

Tuasikal, A. (2013). Fenomenologis Perencanaan dan Penganggaran Pemerintah Daerah. Jurnal Akuntansi Universitas Jember, 11(2).

Miller, P., \& O'Leary, T. (1997). Capital budgeting practices and complementarity relations in the transition to modern manufacture: a field-based analysis. Journal of Accounting Research, 35(2), 257-271.

Abdullah, S., \& Halim, A. (2006). Studi atas belanja modal pada anggaran pemerintah daerah dalam hubungannya dengan belanja pemeliharaan dan sumber pendapatan. Jurnal Akuntansi Pemerintah, 2, 17-32.

Sabrina, A. N. (2009). Pengaruh Partisipasi Penyusunan Anggaran Terhadap Kinerja Aparat Pemerintah Daerah: Budaya Organisasi Dan Komitmen Organisasi Sebagai Variabel Moderating (Survey Pada Pemerintah Daerah Se-Eks Karisidenan Surakarta) (Doctoral dissertation, Universitas Muhammadiyah Surakarta).

Esterberg, K. (2002) Qualitative methods in social research. Boston; McGraw Hill

Creswel, J. W. (2010). Research Design: Qualitative, Quantitative, and Mixed Methods Approaches. Los Angeles: University of Nebraska-Lincoln

Kluvers, R. (2001). An analysis of introducing program budgeting in local government. Public Budgeting \& Finance, 21(2), 29-45.

Franklin, A. L., \& Raadschelders, J. C. (2003). Ethics in Local Government Budgeting: Is There A Gap Between Theory and Practice?. Public Administration Quarterly, 456490.

Froot, K. A., \& Stein, J. C. (1998). Risk management, capital budgeting, and capital structure policy for financial institutions: an integrated approach. Journal of financial economics, 47(1), 55-82.

Mutiarin, D. (2012). Dinamika Kebijakan Anggaran Publik: Konfigurasi dan Dampak Terhadap Pembangunan di Daerah. Makalah Disampaikan Pada Orasi Ilmiah di Universitas Tridharma Balikpapan.

Thompson, J. A. (1987). Agency requests, gubernatorial support, and budget success in state legislatures revisited. The Journal of Politics, 49(3), 756-779. 